\title{
33. BENTHIC FORAMINIFERS AND PALEOBATHYMETRY OF BARROW GROUP (BERRIASIAN-VALANGINIAN) DELTAIC SEQUENCES, SITES 762 AND 763, NORTHWEST SHELF, AUSTRALIA ${ }^{1}$
}

\author{
R. W. Jones ${ }^{2}$ and A.A.H. Wonders ${ }^{2}$
}

\begin{abstract}
Micropaleontological analysis of the Barrow Group of Sites 762 and 763 has been undertaken with a view to determining the stratigraphic age and depositional environment of the unit. The stratigraphic age of the unit is Berriasian-Valanginian at both sites, in line with palynological findings. The unit is interpreted as having been deposited in a marine deltaic environment. Paleobathymetry at Site 763 (proximal) and Site 762 (distal) is interpreted as having been of the order of $100 \mathrm{~m}$ and 200-500 m, respectively. Paleontological evidence for the presence of deep-water submarine fans at Site 763 is lacking. The paleobathymetric significance of the observed variations in the benthic foraminiferal populations at Site 763 remains unclear.
\end{abstract}

\section{INTRODUCTION}

The main reason for drilling on the Exmouth Plateau during Ocean Drilling Program (ODP) Leg 122 was to increase regional geological knowledge by comparing and contrasting the latest Jurassic-earliest Cretaceous sedimentary histories at Sites 762 and 763 (Fig. 1). Site 763 appeared on seismic evidence to have been at that time proximal and Site 762 distal to a terrigenous sediment source from a hinterland to the south (Fig. 2). The main aim of the present work was to determine the depth of depositional environment of the Barrow Group (Valanginian-Berriasian unit on Fig. 2) at Sites 762 and 763. A secondary aim was to confirm the palynologically determined Berriasian-early Valanginian stratigraphic age of the unit. The systematic micropaleontology that underpins the stratigraphic and paleobathymetric interpretation is outlined in Appendix A. Studied samples are listed in Appendix B.

\section{Previous Work}

Tait (1985) has mapped the former Barrow Group delta in the study area. According to his interpretation, it was confined by a system of transforms and spreading axes to the west and by the Flinders Fault to the east and was fed by sediment from the southwest which was channelled to the northeast. It prograded until starved of sediment and formed a final eastwest-trending arcuate front which appears to pass between the locations of Site 763 to the south and Site 762 to the north. The topsets and foresets of the southern area were assigned to the Flacourt Formation and the bottomsets of the northern area to the Malouet Formation. The succeeding unit is the Muderong Shale.

\section{STRATIGRAPHY}

The distributions of microfossils in the Barrow Group of Sites 762 and 763 are given on Tables 1 and 2, respectively. The known stratigraphic ranges of selected key species are given on Figure 3, which is compiled from various published

\footnotetext{
1 von Rad, U., Haq, B. U., et al., 1992. Proc. ODP, Sci. Results, 122: College Station, TX (Ocean Drilling Program).

2 BP Research Centre, Chertsey Road, Sunbury-on-Thames, Middlesex, TW16 7LN, United Kingdom.
}

and unpublished sources. These species, and the absence of older or younger species, indicate a Berriasian-Valanginian age. Palynostratigraphic analyses indicate a Berriasian-early Valanginian age (Brenner, chapter 23, this volume).

\section{PALEOBATHYMETRY OF SITE 763}

The distribution of microfossils in the Barrow Group of Site 763 is given on Table 2.

\section{Indications of a Deltaic Environment}

The foraminiferal suborder ratio (Fig. 4) reveals a dominance of agglutinated Textulariina and calcareous Rotaliina and an absence of porcelaneous Miliolina (which latter feature may simply reflect the poorly advanced state of evolution and dispersal of the Miliolina in the Early Cretaceous). Analogy with modern microfaunas suggests a hyposaline marsh, lagoonal or estuarine or normal marine deltaic environment (Murray, 1973; Boltovskoy and Wright, 1976). The low abundance and dominance and moderately high-diversity values (Fig. 5) are further suggestive of a normal marine deltaic environment.

A more proximal setting can also be ruled out on account of the dissimilarity of the fauna as compared to those of the well-documented sub-environments of the modern Mahakam Delta Plain (van Gorsel, 1988) and Mississippi Delta Plain and active birdfoot (Phleger, 1954, 1955, 1960; Hiltermann and Tüxen, 1978; Haman, 1983; Hiltermann and Haman, 1985). These are characterized by the agglutinating foraminifers Ammoastuta, Ammoscalaria, Ammotium, Arenoparrella, Miliammina, Polysaccammina, Tiptotrocha, and Trochamminita. Many of these genera are restricted to the Cenozoic, but Ammoastuta and Miliammina are also regarded as indicators of marginal marine environments in the middle part of the Cretaceous (Luger, 1988).

A more distal submarine fan setting also appears unlikely on paleontological evidence, although interpreted fan deposits have been identified between Cores 122-763C-5R and 122763B-52X. "Flysch-type"' (see, for instance, Kaminski et al., 1988) benthic and bathypelagic foraminifers are absent (though, again, this may be due to evolutionary rather than environmental effects). However, the recovery of the nasselline radiolarian Eucyrtis? in Core 122-763C-5R may indicate deep water. Modern nassellines are bathypelagic and most 


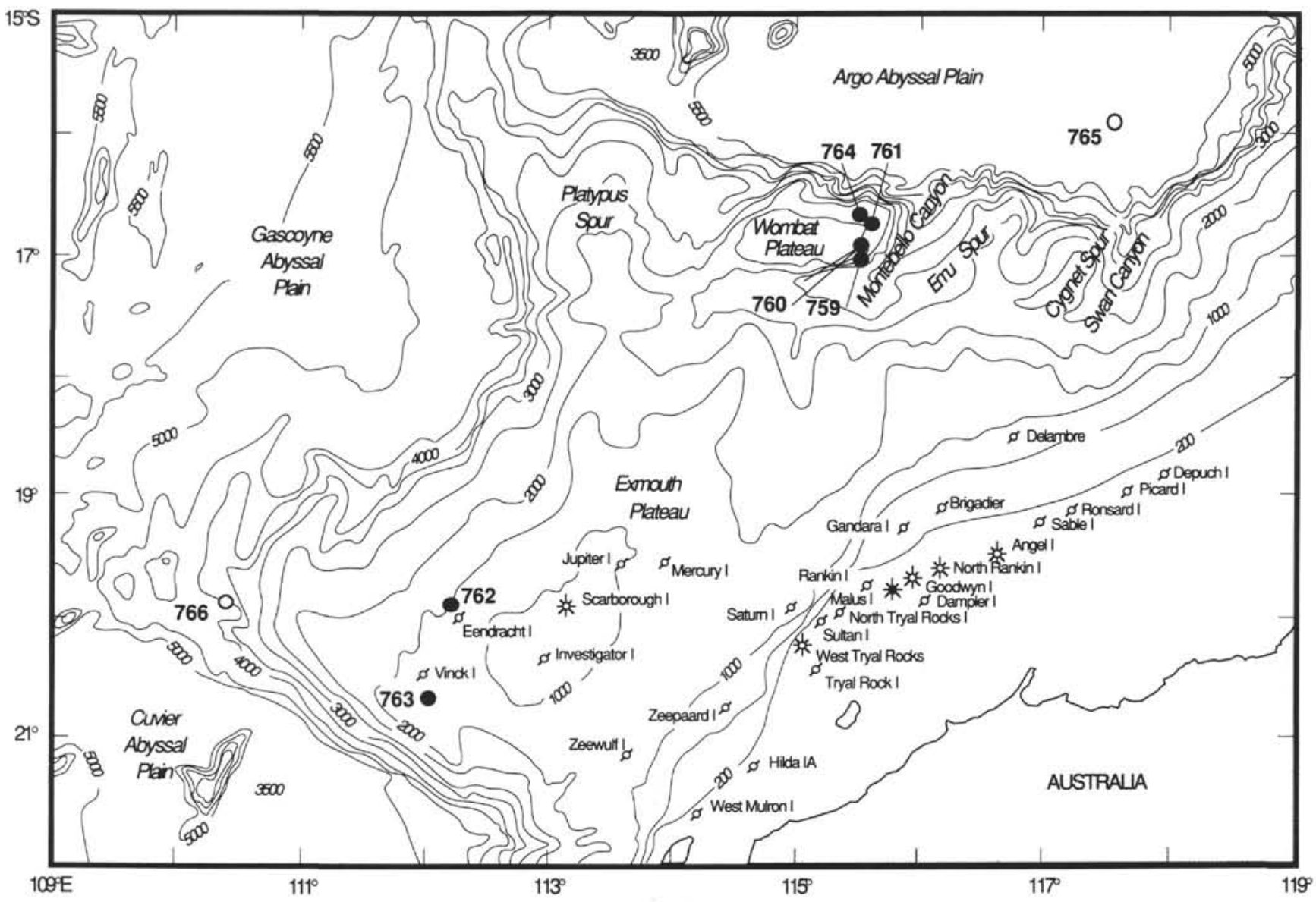

Figure 1. Location map, Sites 762 and 763, Exmouth Plateau, Northwest Shelf, Australia. Closed circles indicate Leg 122 sites, open circles are Leg 123 sites, and other symbols are commercial wells.

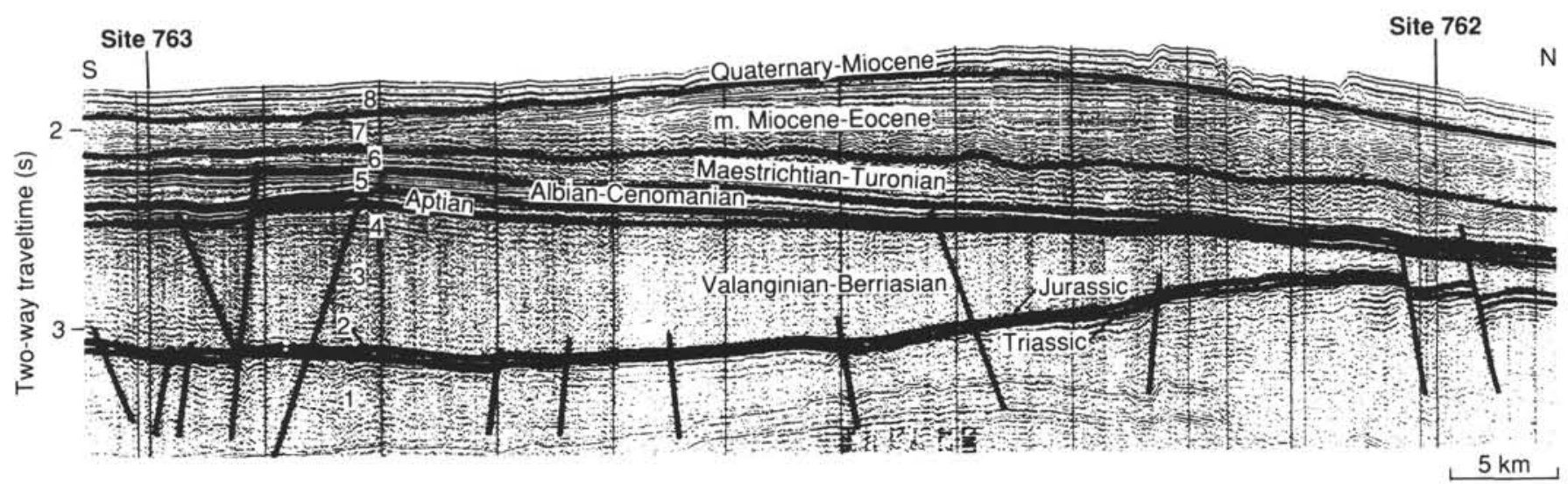

Figure 2. Interpreted seismic section through Sites 762 and 763. Note pronounced thinning of Valanginian-Berriasian (Barrow Group) from south to north.

common in live form in the water column between depths of 200 to more than $2000 \mathrm{~m}$ (their bell-like morphology probably represents an adaptation to life in areas of oceanic upwelling) and dead in underlying sediments. Latest Jurassic to earliest Cretaceous forms were probably also oceanic in their ecological preferences (Dyer and Copestake, 1989).

The precise placement within the delta-?fan system is difficult to determine. However, foraminiferal assemblages from Site 763 are similar to the so-called "Ammodiscus" or "Ammodiscus-Dentalina" assemblages described by Nagy (1985a, 1985b) from the Jurassic Dunlin and Brent Formation deltaics of the Statfjord area of the northern North Sea (analogous in terms of extratropical latitude and probably climate and offshore energy if not necessarily in terms of sediment supply and morphology). These indicate delta top and proximal deltaic marine settings, respectively, characterized by high clastic sediment input (Fig. 6). Similar assemblages also occur in the Paleocene?-Eocene Moray Group deltaics of the central North Sea (authors' unpublished observations). 
Table 1. Distribution of microfossils in the Barrow Group (BerriasianValanginian), Site $\mathbf{7 6 2}$.

\begin{tabular}{|c|c|c|c|c|c|c|c|c|c|c|c|}
\hline$\stackrel{\varphi}{\vec{x}}$ & $\begin{array}{l}0 \\
\dot{x}\end{array}$ & $\begin{array}{l}\mathscr{0} \\
\mathscr{\bullet} \\
\times\end{array}$ & $\begin{array}{l}\infty \\
\infty \\
\times\end{array}$ & $\underset{\substack{x \\
x}}{\infty}$ & $\begin{array}{l}\infty \\
\mathscr{0} \\
\times\end{array}$ & $\begin{array}{c}\infty \\
\mathfrak{w} \\
\times\end{array}$ & $\begin{array}{l}\infty \\
\vec{x}\end{array}$ & $\begin{array}{c}\infty \\
\underset{\times}{\times}\end{array}$ & $\begin{array}{l}\infty \\
N \\
\times\end{array}$ & $\stackrel{\infty}{\vec{x}}$ & Core No. \\
\hline & & $p$ & p & & & & & & $p$ & & Bathysiphon sp. \\
\hline & & p & & & & & & & & & Ammodiscidae Indet. \\
\hline & & & & & & & & & $\mathrm{p}$ & & Haplophragmoides sp. \\
\hline$p$ & & & & & & & & & & & Textularia sp. 1 \\
\hline $\mathrm{p}$ & & & & & & & & & & & P. kummi \\
\hline $\mathrm{p}$ & & & & & & & & & & & Lituolacea Indet. \\
\hline$p$ & & $\mathrm{p}$ & & $\mathrm{p}$ & & & & & & & L. ex gr. muensteri \\
\hline & & & & $\mathrm{p}$ & & & & & & & S. valanginiana \\
\hline$p$ & & & & & & & & & & & Nodosariidae Indet \\
\hline & & & & $\mathrm{p}$ & & & & & & & C. valendisensis \\
\hline $\mathrm{p}$ & & & & & & & & & & & E. caracolla \\
\hline & $\mathrm{p}$ & & $\mathrm{p}$ & & & & & & $\mathrm{p}$ & & Rotaliacea Indet. \\
\hline & & $p$ & $p$ & & & & & & & & Cenosphaera sp. \\
\hline & p & & p & & & & & & & & Macrofossil debris \\
\hline $\mathrm{p}$ & $p$ & & & & & & & & & & Ichthyoliths \\
\hline
\end{tabular}

Note: $\mathrm{p}=$ present $(1-4$ specimens $) ; \mathrm{c}=$ common $\left(>5\right.$ specimens per $10-\mathrm{cm}^{3}$ sample).

\section{Absolute Depth}

The absolute depth of the depositional environment is difficult to determine. However, foraminiferal assemblages from Site 763 plot out in the outer shelf (50-200 m) to upper slope $(200-1000 \mathrm{~m})$ field on a triangular plot of foraminiferal "morphogroups" (Fig. 7). Note that the preponderance of textulariids as opposed to hormosinids within infaunal "morphogroup" C is more indicative of the outer shelf (Jones and Charnock, 1985). Further, foraminiferal assemblages from Site 763 are similar taxonomically to those from the middle to outer shelf (20-110 m) of the modern Niger Delta (Adegoke et al., 1976). Lituolids (including uncoiling forms), textulariids (Textularia, Spiroplectammina), nodosariids (Lenticulina), and sundry rotaliiforms are common to both.

Published bathymetric and paleobathymetric ranges of some of the individual foraminiferal taxa from Site 763 confirm the moderate depth. Lenticulina muensteri is regarded as an indicator of "mid" shelf (50-150 m) and regressive environments in the Jurassic (Johnson, 1976; Haynes, 1981; Stam, 1986; Morris, 1989), and Spirillina minima and various nodosariid and polymorphinid genera are regarded as indicators of outer shelf depths (100-200 m) in the Cretaceous (Sliter and Baker, 1972; Moullade, 1984; Olsson and Nyong, 1984; Olsson, 1988). Forms interpreted by Sliter and Baker (1972), Olsson and Nyong (1984) and Olsson (1988) as indicators of inner and middle shelf depths $(0-30 \mathrm{~m}$ and $30-100 \mathrm{~m}$, respec- tively) are absent. These include miliolids and the nodosariid genus Citharina.

Astrorhizids, ammodiscids, and Ammobaculites reophacoides are regarded by Sliter and Baker (1972) and Moullade (1984) as indicators of slope environments in the Cretaceous. However, many astrorhizids and ammodiscids have upper depth limits as shallow as $30-60 \mathrm{~m}$ in the Holocene of the Mediterranean (Lacroix, 1928, 1929), possibly in response to a "delta-effect" of the type described by Pflum and Frerichs (1976) in the Gulf of Mexico. Further, A. reophacoides occurs in association with shelf species in the Lower Cretaceous of northwest Germany (Bartenstein, 1952; Bartenstein and Bettenstaedt, 1962) and in the North Sea Basin (authors' unpublished observations).

Robertinacean species are regarded by Haynes (1981) as indicators of outer shelf and slope environments in the Holocene. However, their Cretaceous counterparts appear to have been restricted to shelf environments (Sliter and Baker, 1972; Hart, 1984; Moullade, 1984). Their apparent absence in Cretaceous slope environments may be at least in part a function of their low preservation potential below the aragonite compensation depth (M. B. Hart, pers. comm., 1990).

The presence of sighted ostracodes throughout the Barrow Group of Site 763 (see also Damotte, this volume) probably confirms an environment within the photic zone (by analogy with the Holocene, no deeper than about $130 \mathrm{~m}$ ). However, some deeper water ostracodes possess eye tubercles (authors' unpublished observations).

\section{Paleobathymetric Trends}

The uphole replacement (at around the level of Core 122-763C-33R) of an agglutinate-dominated microfauna by one dominated by calcareous benthic foraminifers may be significant. Nagy (1985a, 1985b) and Nagy et al. (1988) interpret calcareous benthic foraminifers as of more open marine aspect than agglutinates. However, this is not to say that they are necessarily of deeper aspect: the agglutinates might represent an (overdeepened) intrashelf basin facies. It is unclear whether the observed uphole trend represents a deepening or a shoaling. It could even represent a response to a change in some parameter other than depth (such as turbidity).

\section{Conclusions}

The Barrow Group succession at Site 763 is believed to have been deposited in a marine delta in water depths of about $100 \mathrm{~m}$. Paleontological evidence for the presence of submarine fan deposits between Cores 122-763C-5R and 122-763B-52X is generally lacking, though the recovery of a nasselline radiolarian in Core $122-763 \mathrm{C}-5 \mathrm{R}$ could be construed as evidence of bathyal bathymetry (water depth $>200 \mathrm{~m}$ ).

The paleobathymetric significance of the observed changes in the benthic foraminiferal populations at around the level of Core $122-763 \mathrm{C}-33 \mathrm{R}$ remains unclear.

\section{PALEOBATHYMETRY OF SITE 762}

The distribution of microfossils in the Barrow Group sequence of Site 762 is given on Table 1.

\section{Indications of a Deltaic Environment}

As in the case of Site 763, the foraminiferal suborder ratio (Fig. 4) suggests a hyposaline marginal marine or normal marine deltaic environment. Abundance and (composite) diversity values from Site 762 (Fig. 5) are very low, which would tend to suggest some form of environmental stress (Murray, 1973). In this particular instance perhaps the most likely contender would be oxygen deficiency. Foraminiferal assemblages from Site 762 contain a higher proportion of calcareous 
R. W. JONES, A.A.H. WONDERS

Table 2. Distribution of microfossils in the Barrow Group (Berriasian-Valanginian), Site 763.

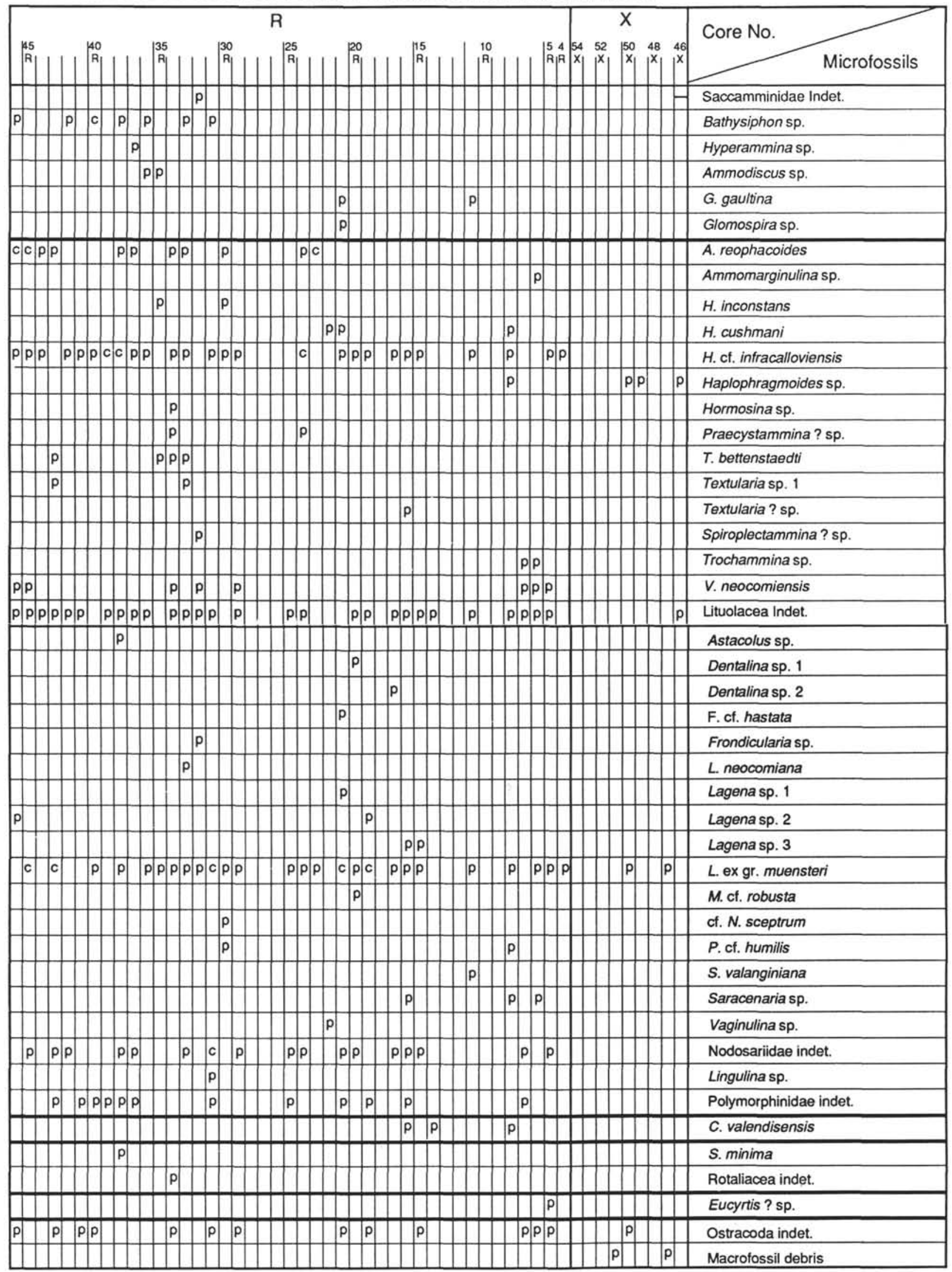

Note: $\mathrm{p}=$ present $(1-4$ specimens $) ; \mathrm{c}=$ common $\left(>5\right.$ specimens per $10-\mathrm{cm}^{3}$ sample). 
benthic foraminifers than those from Site 763 and are closer to (though not as diverse as) the "Dentalina-Nodosaria" assemblages described by Nagy (1985a, 1985b) from the Jurassic deltaics of the northern North Sea (see above). These indicate a distal deltaic marine setting characterized by low clastic sediment input (Fig. 6).

\section{Absolute Depth}

In regard to absolute depth, the foraminiferal "morphogroup" ratio (Fig. 7) suggests an outer shelf (50-200 m) to upper slope (200-1000 m) environment, with the proportion of "morphogroup" A (tubular forms interpreted as suspensionfeeders) further suggesting the latter rather than the former (Jones and Charnock, 1985). The absence of sighted ostracodes probably confirms an environment below the "light floor" $(130 \mathrm{~m})$.

The finding of the pelagic spumelline radiolarian Cenosphaera in Cores $122-762 \mathrm{C}-89 \mathrm{X}$ and $122-762 \mathrm{C}-88 \mathrm{X}$ is significant: modern spumellines are most common in live form between depths of $0-500 \mathrm{~m}$ in the water column (their spherical and spinose morphology probably represents an adaptation to reduce sinking rate and to maintain a position close to the photic zone, where symbiotic zooxanthellae can provide a food source) and in dead form in underlying bottom sediments. Greater depths can probably be ruled out on the basis of the absence of bathypelagic nassellines (see above).

\section{Conclusion}

The Barrow Group succession at Site 762 is believed to have been deposited in a marine delta in water depths of about 200-500 m.

\section{SUMMARY OF RESULTS}

Micropaleontological analysis indicates that the Barrow Group succession of Sites 762 and 763 is of BerriasianValanginian age.

Analogy with ancient and modern counterparts indicates that Barrow Group microfossil assemblages from Sites 763 and 762 were deposited in a marine delta. Paleobathymetry at Site 763 (proximal) and Site 762 (distal) is interpreted as having been of the order of $100 \mathrm{~m}$ and $200-500 \mathrm{~m}$, respectively. Paleontological evidence for the presence of deepwater submarine fans at Site 763 is lacking. The paleobathymetric significance of the observed variations in the benthic foraminiferal populations at Site 763 remains unclear.

\section{Regional Implications}

Paleontological evidence points to a greater paleobathymetry at Site 762 than at Site 763 throughout the studied interval. The apparent Triassic-Jurassic structural "high" underlying Site 762 (see Fig. 2) may therefore be a secondary rather than a primary feature. It may be due to differential subsidence at the two sites brought about by differences in deposited thickness of Barrow Group sediments.

\section{ACKNOWLEDGMENTS}

We wish to acknowledge Prof. M. B. Hart for his constructive criticism and BP for permission to publish.

\section{REFERENCES}

Adegoke, O., Omatsola, N., and Salami, N., 1976. Benthonic foraminiferal biofacies off the Niger Delta. Proc. 1st Int. Symp. on Benthonic Foraminifera, 279-292.

Bartenstein, H., 1952. Taxonomische Bemerkungen zu den Ammobaculites, Haplophragmium, Lituola und verwandten Gattungen (For.). Senckenbergiana, 33:313-342.
1974. Upper Jurassic-Lower Cretaceous primitive arenaceous foraminifera from DSDP Sites 259 and 261, eastern Indian Ocean. In Veevers, J. J., Heirtzler, J. R., et al., Init. Repts. DSDP, 27: Washington (U.S. Govt. Printing Office), 683-695.

Bartenstein, H., and Bettenstaedt, F., 1962. Marine Unterkreide (Boreal und Tethys). In Simon, W., and Bartenstein, H. (Eds.), Leitfossilien der Mikropaläontologie: Berlin (Borntraeger), 225297.

Bartenstein, H., and Brand, E., 1951. Mikropaläontologische Untersuchungen zur Stratigraphie des nordwestdeutschen Valendis. Abh. Senckenb. Naturforsch. Ges., 485:239.

Basov, I. A., Bulynnikova, S. P., and Kuznetsova, K. I., 1973. Foraminifera from the Jurassic-Cretaceous boundary beds in the U.S.S.R. (Boreal Realm). In Casey, R., and Rawson, P. F. (Eds.), The Boreal Lower Cretaceous: Liverpool (Seel House Press), 401-406.

Bettenstaedt, F., and Spiegler, D., 1975. Zur Evolution von Lagena in der tieferen Unterkreide NW-Deutschlands. Mitt. Geol.-Paläontol. Inst. Univ. Hamburg, 44:11-44.

Boltovskoy, E., and Wright, R., 1976. Recent Foraminifera: The Hague (W. Junk).

Campbell, A. S., and Moore, R. C., 1954. Treatise on Invertebrate Paleontology, Protista 3, Chiefly Radiolarians and Tintinnines. Geol. Soc. Am. and Kansas Univ. Press.

Chamney, T. P., 1976. Foraminiferal morophogroup symbol for paleoenvironmental interpretation of drill cutting samples: Arctic America. Proc. 1st Int. Symp. on Benthonic Foraminifera, 585624.

Crespin, I., 1963. Lower Cretaceous arenaceous foraminifera of Australia. Bull. Bur. Miner. Resour. Geol. Geophys. Aust., 66:1-110.

Decker, K., and Rögl, F., 1988. Early Cretaceous agglutinated foraminifera from limestone-marl rhythmites of the Gresten Klippen Belt, Eastern Alps, Austria. Proc. 2nd Int. Workshop on Agglutinated Foraminifera, 1-60.

Desai, D., and Banner, F. T., 1987. The evolution of Early Cretaceous Dorothiinae (Foraminiferida). J. Micropaleontol., 6:13-27.

Dyer, R., and Copestake, P., 1989. A review of late Jurassic to earliest Cretaceous radiolaria and their biostratigraphic potential to petroleum exploration in the North Sea. In Batten, D. J., and Keen, M. C. (Eds.), Northwest European Micropalaeontology and Palynology: Chichester (Ellis Horwood), 214-235.

Ellis, B. F., and Messina, A., 1940 et seg. Catalogue of Foraminifera Washington D.C. (American Museum of Natural History).

Gradstein, F. M., Gibling, M. R., Jansa, L. F., Kaminski, M. A., Ogg, J. G., Sarti, M., Thurow, J. W., von Rad, U., and Westermann, G.E.G., 1989. Mesozoic Stratigraphy of Thakkhola, Central Nepal. Spec. Rep. Cent. Mar. Geol. Dalhousie Univ., 1:1-115.

Haman, D., 1983. Modern Textulariina (Foraminiferida) from the Balize Delta, Louisiana. Proc. 1st Workshop on Arenaceous Foraminifera, 59-87.

Hart, M. B., 1984. The Superfamily Robertinacea in the Lower Cretaceous of the UK and adjacent areas of NW Europe. Proc. 2nd Int. Symp. on Benthonic Foraminifera, 289-298.

Hart, M. B., Bailey, H. W., Fletcher, B., Price, R., and Swiecicki, A., 1981. Cretaceous. In Jenkins, D. G., and Murray, J. W. (Eds.), Stratigraphical Atlas of Fossil Foraminifera: Chichester (Ellis Horwood), 149-227.

Haynes, J. R., 1981. Foraminifera: London (MacMillan).

Hiltermann, H., and Haman, D., 1985. Sociology and synecology of brackish-water foraminifera and thecamoebinids of the Balize Delta, Louisiana. Facies, 13:287-294.

Hiltermann, H., and Tüxen, J., 1978. Die Biozonosen der Phlegerschen Benthos-Faunen vom Mississippi-Sund und Delta. Paläontol. Z., 52:271-279.

Johnson, B., 1976. Ecological ranges of selected Toarcian and Domerian (Jurassic) foraminiferal species from Wales. Proc. 1st Int. Symp. on Benthonic Foraminifera, 545-556.

Jones, R. W., 1984. Late Quaternary benthonic foraminifera from deep-water sites in the North-East Atlantic and Arctic [Ph.D dissert.]. Univ. Coll. Wales, Aberystwyth.

Jones, R. W., and Charnock, M. A., 1985. "Morphogroups" of agglutinating foraminifera: their life positions and feeding habits and potential applicability in (paleo) ecological studies. Rev. Paleobiol., 4:311-320. 
Kaminski, M. A., Gradstein, F. M., Berggren, W. A., Geroch, S., and Beckmann, J. P., 1988. Flysch-Type agglutinated assemblages from Trinidad: taxonomy, stratigraphy and paleobathymetry. Proc. 2nd Int. Workshop on Agglutinated Foraminifera, 155-229.

Krasheninnikov, V. A., 1973. Cretaceous benthonic foraminifera, Leg 20, Deep Sea Drilling Project. In Heezen, B. C., MacGregor, I. D., et al., Init. Repts. DSDP, 20: Washington (U.S. Govt. Printing Office), 205-219.

1974. Upper Cretaceous benthonic agglutinated foraminifera, Leg 27 of the Deep Sea Drilling Project. In Veevers, J. J., Heirtzler, J. R., et al., Init. Repts. DSDP, 27: Washington (U.S. Govt Printing Office), 631-662.

Kuznetsova, K. I., 1974. Distribution of benthonic foraminifera in Upper Jurassic and Lower Cretaceous deposits at Site 261, in the eastern Indian Ocean. In Veevers, J. J., Heirtzler, J. R., et al., Init. Repts. DSDP, 27: Washington (U.S. Govt. Printing Office), 673-681.

Lacroix, E., 1928. De la présence d'une faune d'Astrorhizidés tubulaires dans des fonds littoraux de Saint-Raphaël a Monaco. Bull. Inst. Oceanogr. Monaco, 527:1-16.

1929. Les Astrorhizidés du littoral méditerranéen entre Saint-Raphael et Monaco. Bull. Inst. Oceanogr. Monaco, 545:122.

Loeblich, A. R., Jr., and Tappan, H., 1964. Treatise on Invertebrate Paleontology, Protista 2, Sarcodina, chiefly "Thecamoebians" and Foraminiferida. Geol. Soc. Am. and Univ. of Kansas Press. , 1988. Foraminiferal Genera and Their Classification: New York (Van Nostrand Reinhold).

Løfaldli, M., and Nagy, J., 1983. Agglutinating foraminifera in Jurassic and Cretaceous dark shales in southern Spitsbergen. Proc. 1st Workshop on Arenaceous Foraminifera, 91-107.

Lott, G. K., Fletcher, B. N., and Wilkinson, I. P., 1986. The stratigraphy of the Lower Cretaceous Speeton Clay Formation in a cored borehole off the coast of northeast England. Proc. Yorks. Geol. Soc., 46:39-56.

Luger, P., 1988. Campanian to Paleocene agglutinated foraminifera from freshwater-influenced marginal marine (Deltaic) sediments of Southern Egypt. Proc. 2nd Int. Workshop on Agglutinated Foraminifera, 255-263.

Morris, P. H., 1989. The Aalenian to Callovian (Middle Jurassic). In Jenkins, D. G., and Murray, J. W. (Eds.), Stratigraphical Atlas of Fossil Foraminifera (2nd ed.): Chichester (Ellis Horwood), 189-236.

Moullade, M., 1961. Quelques foraminiferes et Ostracodes nouveaux du Crétacé inférieur vocontien. Rev. Micropaleontol., 3:213-216. 1966. Ětude stratigraphique et micropaléontologique du Crétacé Inférieur de la "Fosse Vocontienne" [Ph.D. dissert.]. Univ. Lyon.

1984. Intérêt des petits foraminifères benthiques "profonds" pour la biostratigraphie et l'analyse des paléoenvironnements océaniques Mésozoïques. Proc. 2nd Int. Symp. Benthic Foraminifera, 429-464.

Murray, J. W., 1973. Distribution and Ecology of Living Benthic Foraminiferids: London (Heinemann Educational Books).

Nagy, J., 1985a. Jurassic foraminiferal facies in the Statfjord area, northern North Sea, I. J. Pet. Geol., 8:273-295.

1985b. Jurassic foraminiferal facies in the Statfjord area, northern North Sea, II. J. Pet. Geol., 8:389-404.

Nagy, J., Løfaldli, M., and Backstrom, S. A., 1988. Aspects of foraminiferal distribution and depositional conditions in Middle Jurassic to Early Cretaceous Shales in Eastern Spitsbergen. Proc. 2nd Int. Workshop on Agglutinated Foraminifera, 287-300.

Olsson, R. K., 1988. Foraminiferal modelling of sea-level change in the Late Cretaceous of New Jersey. Spec. Publ. Soc. Econ. Paleontol. Mineral., 42:289-297.

Olsson, R. K., and Nyong, E. E., 1984. A paleoslope model for Campanian-Lower Maestrichtian foraminifera of New Jersey and Delaware. J. Foraminiferal Res., 14:50-68.

Pflum, C. E., and Frerichs, W. E., 1976. Gulf of Mexico deep-water foraminifers. Spec. Publ. Cushman Found. Foraminiferal Res., 14:1-122.

Phleger, F. B., 1954. Ecology of foraminifera and associated microorganisms from Mississippi Sound and environs. AAPG Bull., 38:584-647.

1955. Ecology of foraminifera in southeastern Mississippi Delta area. AAPG Bull., 39:712-752.
1960. Ecology and Distribution of Recent Foraminifera: Baltimore (John Hopkins Press).

Sanfilippo, A., and Riedel, W. R., 1985. Cretaceous radiolaria. In Bolli, H. M., Saunders, J. B., and Perch-Nielsen, K. (Eds.), Plankton Stratigraphy: Cambridge (Cambridge Univ. Press), 573-630.

Sliter, W. V., and Baker, R. A., 1972. Cretaceous bathymetric distribution of benthonic foraminifers. J. Foraminiferal Res., 2:167-183.

Stam, B., 1986. Quantitative analysis of Middle and Late Jurassic foraminifera from Portugal and its implications for the Grand Banks of Newfoundland. Utrecht Micropaleontol. Bull., 34:1-167.

Sztejn, J., 1988. Benthic foraminifera from the Ryazanian and Lower Valanginian in the Polish Lowlands. Proc. 3rd Int. Symp. on Benthonic Foraminifera, 271-280.

Tait, A. M., 1985. A depositional model for the Dupuy Member and the Barrow Group in the Barrow Sub-Basin, North-Western Australia. APEA J., 25:282-290.

van Gorsel, J. T., 1988. Biostratigraphy in Indonesia: methods, pitfalls and new directions. Proc. Indonesian Petrol. Assoc. 17th Ann. Conv., 275-300.

Date of initial receipt: 4 June 1990

Date of acceptance: 25 February 1991

Ms 122B-174

APPENDIX A

\section{SYSTEMATIC MICROPALEONTOLOGY FORAMINIFERS}

The suprageneric classification adopted herein is essentially that of Loeblich and Tappan (1964), with some modifications after Haynes (1981). Original generic designations of all species are given in order to enable interested readers to compare the figures in this paper with the type figures (by reference to the Ellis and Messina Catalogue of Foraminifera (1940 et seq.)). Specimens figured in this paper are housed at the BP Research Centre, Sunbury-on-Thames.

\section{Suborder TEXTULARIINA \\ Superfamily AMMODISCACEA \\ Family SACCAMMINIDAE}

Saccamminid indet.

\section{Family ASTRORHIZIDAE}

Bathysiphon sp. Close to Bathysiphon sp. as figured by Bartenstein (1974) from the Upper Jurassic-Lower Cretaceous of DSDP Sites 259 and 261 , eastern Indian Ocean.

Hyperammina sp. Close to Hyperammina spp. B and C as figured by Crespin (1963) from the Lower Cretaceous of Australia and $H$. sp. 1 as figured by Bartenstein (1974) from the Upper Jurassic-Lower Cretaceous of DSDP Sites 259 and 261, eastern Indian Ocean.

\section{Family AMMODISCIDAE}

Ammodiscus sp.

Glomospira gaultina (Berthelin) [Ammodiscus gaultinus Berthelin] Glomospira sp.

\section{Superfamily LITUOLACEA}

Lituolacea indet.

\section{Family LITUOLIDAE}

Ammobaculites reophacoides Bartenstein. Differs from the types only in the proportionately larger diameter of the planispiral portion. In this respect it is close to A. subcretaceus Cushman and Alexander, from which it differs in its inflated test form.

Ammomarginulina sp.

Haplophragmium inconstans inconstans Bartenstein and Brand. Appears identical to the specimens figured by Kuznetsova (1974) from DSDP Site 261, eastern Indian Ocean.

Haplophragmoides cushmani Loeblich and Tappan This species was originally described from the Albian of the United States. Our specimens are close to that figured by Bartenstein and Brand (1951) from the Valanginian-Hauterivian of northwest Germany and to that figured (as Haplophragmoides nononoides (Hauesler) 
(sic)) by Gradstein et al. (1989) from the Tithonian of central Nepal.

Haplophragmoides cf. infracalloviensis Dain. Appears identical to specimens figured under this designation by Løfaldli and Nagy (1983) from the Volgian (boreal equivalent of the early Berriasian and Tithonian) of Spitzbergen. Also to $H$. cf. concavus (Chapman) as recently figured by Lott et al. (1986) from the Ryazanian (boreal equivalent of the late Berriasian) of the Speeton Clay Formation of northeast England.

Haplophragmoides sp. A strongly biumbilicate form, approaching $H$. nonioninoides of authors (not Reuss).

\section{Hormosina sp.}

Praecystammina? sp. The apparently streptospiral coiling and areal aperture indicate placement in the genus Praecystammina Krasheninnikov, previously known only from Late Cretaceous deepwater sediments (e.g., Indian and Pacific oceans (Krasheninnikov (1973, 1974)). Trochospirally coiled forms with areal apertures belong in Pseudotrochammina Frerichs.

\section{Family TEXTULARIIDAE}

Textularia bettenstaedti Bartenstein and Oertli. Appears identical to the specimen recently figured under this designation by Sztejn (1988) from the Ryazanian of the Polish Lowlands. Also to $T$. depravata Schwager as figured by Kuznetsova (1974) from the Upper Jurassic-Lower Cretaceous of DSDP Site 261, eastern Indian Ocean. $T$. foeda Reuss is morphologically similar, but records indicate that this is a stratigraphically younger (Barremian-Albian) species.

Textularia sp. 1. Close to T. chapmani Lalicker. However, records indicate that this is a stratigraphically younger (Albian-Cenomanian) species.

Textularia? sp. Close to $T$. inversa (Terquem) as figured by Kuznetsova (1974) from the Upper Jurassic-Lower Cretaceous of DSDP Site 261, eastern Indian Ocean. The absence through breakage of the initial part of the test renders confirmation of the identification impossible.

Spiroplectammina? sp. Arguably a growth stage of the ultimately uniserial genus Ammobaculoides.

\section{Family TROCHAMMINIDAE}

Trochammina sp. A distinctive high-spired Trochammina close to $T$. gryci Tappan and to $T$. topagorukensis Tappan, originally described from the Upper Jurassic of the arctic slope of Alaska, and subsequently recorded from the Oxfordian-Valanginian of Spitzbergen by Løfaldli and Nagy (1983). However, it differs from the former in possessing fewer chambers per whorl and from the latter in possessing radial sutures on the spiral side. Compressed specimens recall both $T$. neocomiana Myatliuk and $T$. depressa Lozo. T. neocomiana was originally described from the Barremian of the U.S.S.R. and has subsequently been recorded from the Berriasian of that country (Basov et al., 1973), while $T$. depressa was originally described from the Comanchean (broadly AptianAlbian) of Texas and has subsequently been recorded in the Ryazanian (boreal equivalent of the late Berriasian) to early Barremian of northwest Europe (Hart et al., 1981).

\section{Family VERNEUILINIDAE}

Protomarssonella kummi (Zedler) [Marssonella kummi Zedler]. Appears identical to the specimens recently figured by Desai and Banner (1987) from the Hauterivian of Speeton. The total range of this species is Valanginian-Hauterivian.

Verneuilinoides neocomiensis (Myatliuk) s.l. [Verneuilina neocomiensis Myatliuk]. Included here are not only forms which are triserial throughout and therefore typical Verneuilinoides, but also some which are more loosely coiled and tend toward biseriality or semi-uniseriality, thereby approaching Gaudryina, Gaudryinella, and Pseudobolivina (see Chamney $(1976,1978)$ on the difficulties of separating these genera). Certain of the latter bear a close resemblance (particularly in terms of apertural characteristics) to specimens of Gaudryina tailleuri Tappan (1962) from the Albian and older Fortress Mountain Formation of the arctic slope of
Alaska and (to a slightly lesser extent) to the "Neocomian" (?Barremian) G. tappanae Chamney from Rock Unit 1 of the Mount Goodenough section, Aklavik Range, District of Mackenzie, Canada.

\section{Suborder ROTALIIDAE \\ Superfamily NODOSARIACEA \\ Family NODOSARIIDAE}

Generic placement within this group follows Loeblich and Tappan (1964). I have not recognized any of the genera distinguished solely on the basis of surface ornamentation by Loeblich and Tappan (1988).

Astacolus sp. Close to A. dilectus (Reuss), as figured by Kuznetsova (1974) from the Upper Jurassic-Lower Cretaceous of DSDP Site 261, eastern Indian Ocean. (1983) from the Albian of DSDP Site 511, Falkland Plateau.

Dentalina sp. 2. Appears identical to D. sp. 2 Bartenstein and Brand from the Valanginian of northwest Germany.

Frondicularia cf. hastata Roemer. Probably a megalospheric juvenile of this species.

Frondicularia sp. Close to $F$. concinna Koch, but lacks the longitudinal ornament.

Lagena neocomiana (Bartenstein and Brand) [L. apiculata (Reuss) var. neocomiana Bartenstein and Brand] Oolina apiculata Reuss possesses a radiate aperture and is in fact the type-species of the genus Reussoolina Colom, 1956. The erstwhile variety neocomiana is therefore herein treated as a distinct species of Lagena. $L$. hauteriviana hauteriviana Bartenstein and Brand, which evolved from L. neocomiana at the base of the Hauterivian (Bettenstaedt and Spiegler, 1975) differs in being more elongate-ovate.

Lagena sp. 1. Close to the Hauterivian-Barremian form $L$. hauteriviana cylindracea Bartenstein and Brand, but differs in possessing costate ornament.

Lagena sp. 2. Appears identical to L. oxystoma Reuss as figured by Bartenstein and Brand (1951) and Bartenstein and Bettenstaedt (1962) from the Valanginian and Hauterivian-Barremian respectively of northwest West Germany, but unlikely to be conspecific with Reuss's original from the Tertiary. One specimen appears to possess apertures at either end, and might represent the broken terminal portion of a multilocular foraminifer such as Marginulinopsis foeda (Reuss) or M. gracilissima (Reuss).

Lagena sp. 3

Lenticulina ex gr. muensteri (Roemer) [Robulina muensteri Roemer]. All inornate lenticulines are herein referred to this morphologically plastic relict Jurassic group. As herein interpreted, it includes not only forms close to L. muensteri s.s. (Pl. 2, Fig. 9), but also uncoiling forms approaching the essentially Valanginian species $L$. subangulata (Reuss) (PI. 2, Fig. 10) and forms with apparent incipient sutural nodosity approaching the Valanginian-early Hauterivian species $L$. nodosa (Reuss).

Marginulinopsis $\mathrm{cf}$. robusta (Bartenstein and Brand) [Lenticulina (Marginulinopsis) robusta Bartenstein and Brand]. Close to the types, but has fewer and stronger longitudinal costae.

cf. Nodosaria sceptrum Reuss. Fragments tentatively assigned to this species on the basis of the similarity of their ornament.

Pseudonodosaria cf. humilis (Roemer) [Nodosaria humilis Roemer]. Appears identical to Pseudoglandulina cf. humilis (Roemer) as figured by Bartenstein and Brand (1951) from the Valanginian of northwest West Germany. Close to Rectoglandulina humilis (Roemer) as figured by Kuznetsova (1974) from the Upper JurassicLower Cretaceous of DSDP Site 261, eastern Indian Ocean, and to Pseudonodosaria humilis (Roemer) as figured by Lott et al. (1986) from the Valanginian-Hauterivian of the Speeton Clay Formation, northeast England. The identity with Roemer's original from the Cretaceous Kreideformation of Germany cannot be confirmed.

Saracenaria valanginiana (Bartenstein and Brand) [ Lenticulina (Saracenaria) valanginiana Bartenstein and Brand]

Saracenaria sp. Close to $S$. topagorukensis Tappan from the Upper Jurassic of the arctic slope of Alaska.

Vaginulina sp. Close to both $V$. incurvata (Reuss) and $V$. exilis (Reuss) as figured by Kuznetsova (1974) from the Upper JurassicLower Cretaceous of DSDP Site 261, eastern Indian Ocean. 
Nodosariidae indet.

Family LINGULINIDAE

Lingulina sp. Close to the Early Cretaceous species $L$. nodosaria Reuss, but differs in lacking a lobulate periphery. In this respect it approaches L. semiornata var. crassa Chapman from the AptianAlbian of Surrey, southeast England, from which it differs in lacking sutural ornament. The presence of weak longitudinal ridges on the present form is notable, and calls to mind the essentially Early Jurassic $L$. tenera plexus.

\section{Family POLYMORPHINIDAE Polymorphinid indet. \\ Superfamily ROBERTINACEA Family CONORBOIDIDAE}

Conorboides valendisensis Bartenstein and Brand

Family EPISTOMINIDAE

Epistomina caracolla (Roemer) [Gyroidina caracolla Roemer]

Superfamily ROTALIACEA

Rotaliacea indet.

Superfamily SPIRILLINACEA

Family SPIRILLINIDAE

Spirillina minima Schacko. Appears identical to the types from the Cretaceous of Germany and to the specimens figured by Kuznetsova (1974) from the Upper Jurassic-Lower Cretaceous of DSDP Site 261, eastern Indian Ocean. Similar specimens from the Berriasian-Barremian of France and Germany have been described by Moullade $(1961,1966)$ and more recently by Decker and Rögl (1988) (as S. neocomiana Moullade).

\section{RADIOLARIANS}

The suprageneric classification adopted herein is essentially that of Campbell and Moore (1954), with some modifications after Sanfilippo and Riedel (1985) and Dyer and Copestake (1989): generic assignment is provisional only (see also Blome, this volume).

$$
\begin{gathered}
\text { Suborder SPUMELLINA } \\
\text { Superfamily LIOSPHAERICAE } \\
\text { Affinity uncertain }
\end{gathered}
$$

Cenosphaera sp.

\section{Suborder NASSELLINA}

Affinities uncertain

Eucyrtis? sp. The present specimen is close to representatives of the genus Eucyrtis as figured by Sanfilippo and Riedel (1985), notably to $E$. hanni s.l., which ranges from Berriasian-Aptian and is known to occur in the southern Pacific. However, its cephalis is proportionately larger and lacks an apical horn and its distal segments are unornamented.

\section{APPENDIX B}

\section{STUDIED SAMPLES}

$122-762 \mathrm{C}-81 \mathrm{X}-1,60-62 \mathrm{~cm}$ $122-762 \mathrm{C}-82 \mathrm{X}-2,60-62 \mathrm{~cm}$ $122-762 \mathrm{C}-84 \mathrm{X}-\mathrm{CC}$

$122-762 \mathrm{C}-85 \mathrm{X}-2,61-63 \mathrm{~cm}$ $122-762 \mathrm{C}-86 \mathrm{X}-1,60-62 \mathrm{~cm}$ $122-762 \mathrm{C}-87 \mathrm{X}-1,60-62 \mathrm{~cm}$ $122-762 \mathrm{C}-88 \mathrm{X}-1,61-63 \mathrm{~cm}$ $122-762 \mathrm{C}-89 \mathrm{X}-3,60-62 \mathrm{~cm}$ $122-762 \mathrm{C}-90 \mathrm{X}-1,60-62 \mathrm{~cm}$ $122-762 \mathrm{C}-91 \mathrm{X}-1,61-63 \mathrm{~cm}$ 122-763B-46X-2, $110-112 \mathrm{~cm}$ $122-763 \mathrm{~B}-47 \mathrm{X}-2,78-80 \mathrm{~cm}$ 122-763B-49X-2, $109-111 \mathrm{~cm}$ 122-763B-50X-2, 107-109 cm 122-763B-51X-2, 109-111 cm 122-763B-52X-CC

122-763B-53X-1, 109-111 cm

122-763B-54X-1, 95-97 cm

122-763C-4R-CC

122-763C-5R-CC

$122-763 C-6 R-3,28-30 \mathrm{~cm}$

122-763C-7R-2, 109-111 cm $122-763 \mathrm{C}-8 \mathrm{R}-3,109-111 \mathrm{~cm}$ 122-763C-9R-3, 107-109 cm 122-763C-10R-3, 65-68 cm 122-763C-11R-1, 114-116 cm 122-763C-12R-1, 107-109 cm 122-763C-13R-2, 110-112 cm 122-763C-14R-2, 109-111 cm 122-763C-15R-1, 109-111 cm 122-763C-16R-2, 109-111 cm
122-763C-17R-2, 109-111 cm 122-763C-18R-2, 107-111 cm $122-763 \mathrm{C}-19 \mathrm{R}-2,109-111 \mathrm{~cm}$ 122-763C-20R-2, 109-111 cm 122-763C-21R-2, 109-111 cm 122-763C-22R-2, 107-110 cm 122-763C-23R-2, 110-112 cm $122-763 \mathrm{C}-24 \mathrm{R}-2,107-109 \mathrm{~cm}$ 122-763C-25R-2, 109-111 cm $122-763 \mathrm{C}-26 \mathrm{R}-2,108-110 \mathrm{~cm}$ $122-763 \mathrm{C}-27 \mathrm{R}-2,109-111 \mathrm{~cm}$ $122-763 \mathrm{C}-28 \mathrm{R}-2,108-110 \mathrm{~cm}$ 122-763C-29R-2, 106-109 cm 122-763C-30R-2, 109-111 cm 122-763C-31R-1, 109-111 cm 122-763C-32R-2, 110-112 cm 122-763C-33R-2, 109-111 cm 122-763C-34R-2, 109-111 cm $122-763 \mathrm{C}-35 \mathrm{R}-2,109-111 \mathrm{~cm}$ $122-763 \mathrm{C}-36 \mathrm{R}-1,108-110 \mathrm{~cm}$ 122-763C-37R-2, 109-111 cm 122-763C-38R-2, 109-111 cm $122-763 \mathrm{C}-39 \mathrm{R}-2,109-111 \mathrm{~cm}$ 122-763C-40R-2, 109-111 cm 122-763C-41R-3, 110-112 cm 122-763C-42R-2, 112-114 cm $122-763 \mathrm{C}-43 \mathrm{R}-2,107-109 \mathrm{~cm}$ $122-763 \mathrm{C}-44 \mathrm{R}-2,110-112 \mathrm{~cm}$ 122-763C-45R-2, 110-112 cm 122-763C-46R-2, 109-111 cm 


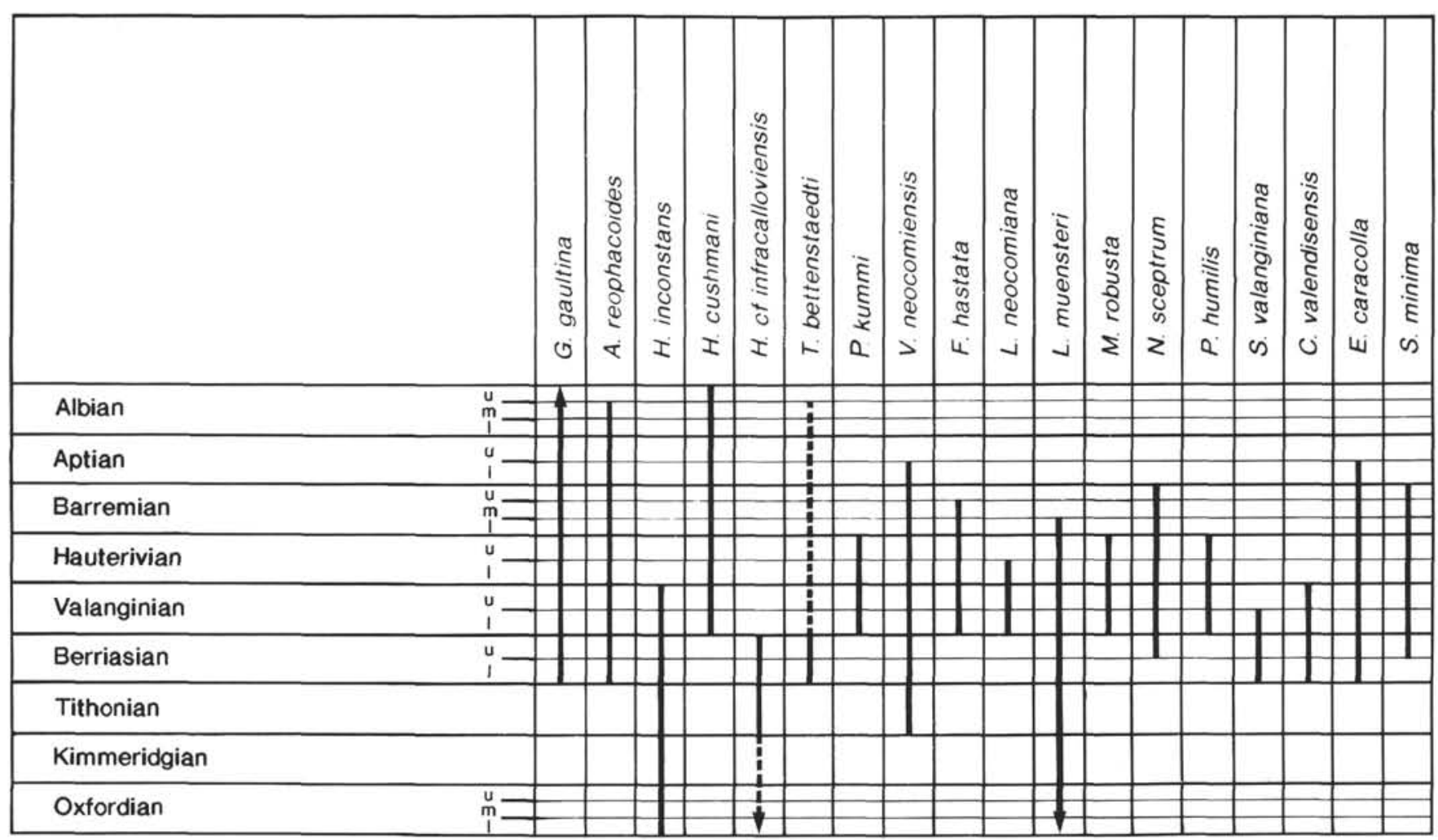

Figure 3. Known stratigraphic ranges of microfossils found in the Barrow Group, Sites 762 and 763.

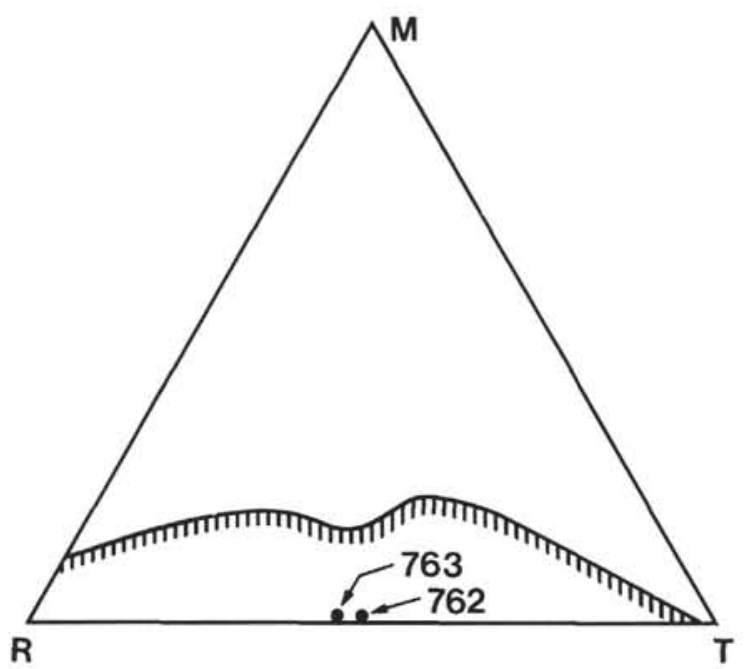

Figure 4. Triangular plot of foraminiferal suborders, Sites 762 and 763. $\mathrm{T}=$ Textulariina $\mathbf{M}=$ Miliolina $\mathbf{R}=$ Rotaliina. Enclosed area is the shelf sea field of Murray (1973). Note that bathyal and abyssal assemblages also plot out in this field (Jones, 1984).

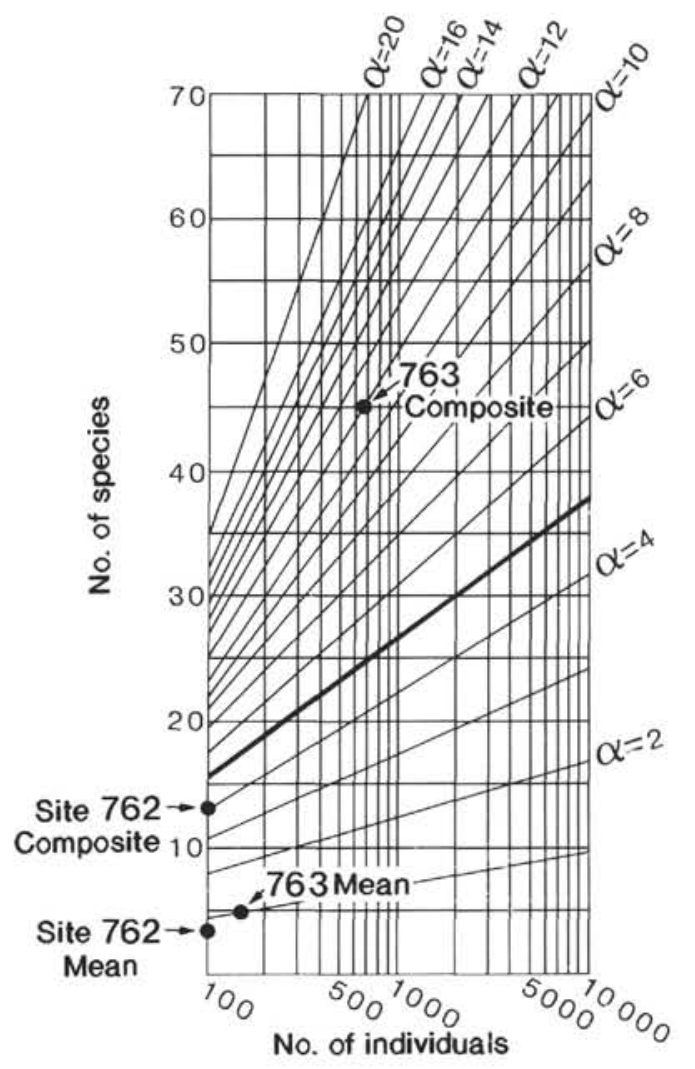

Figure 5. Fisher $(\alpha)$ diversity plot of foraminifers, Sites 762 and 763. 


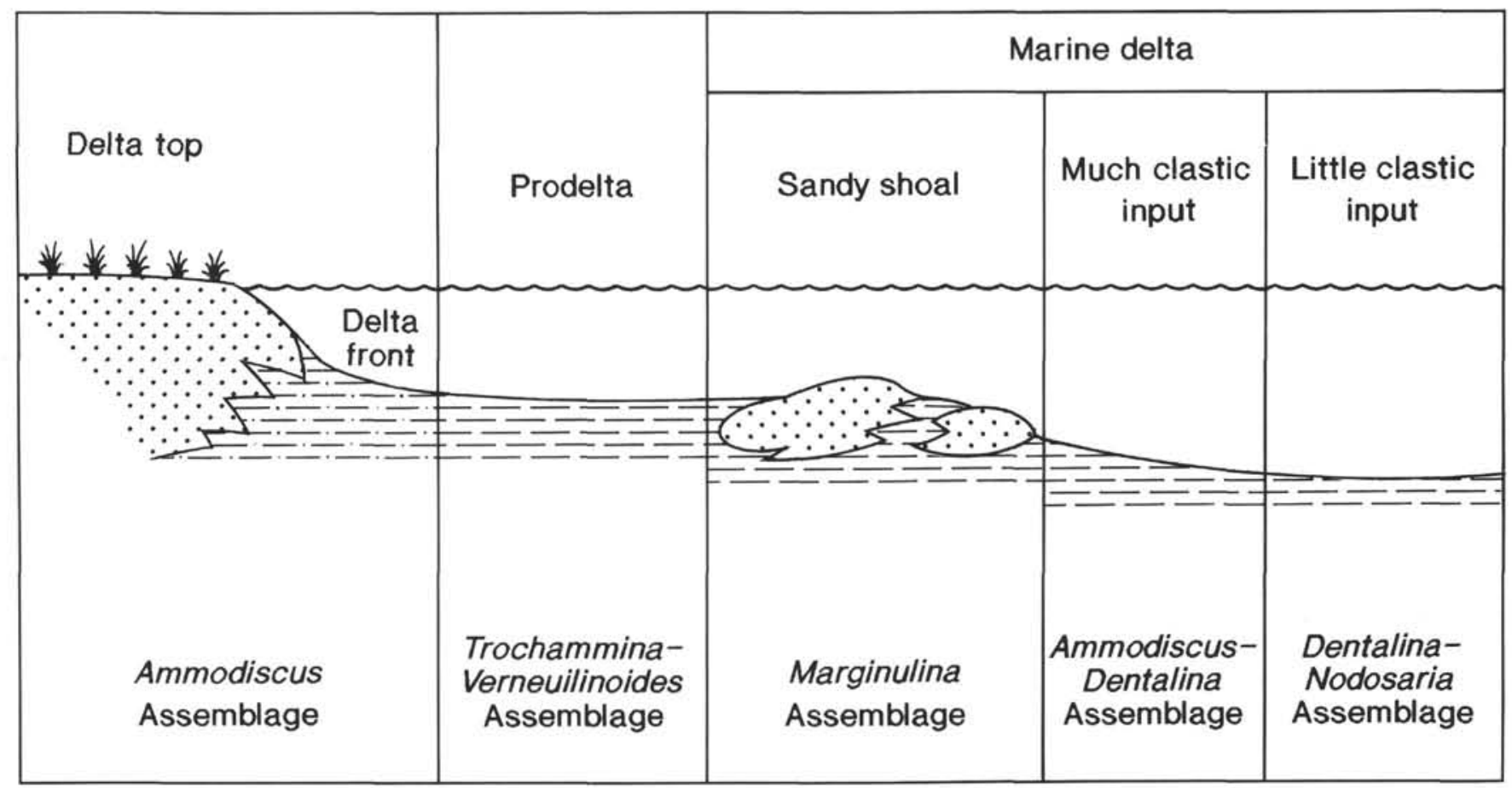

Figure 6. Conceptual model of foraminiferal distribution in deltaic sub-environments in the Mesozoic (after Nagy, 1985a, 1985b). No scale implied.

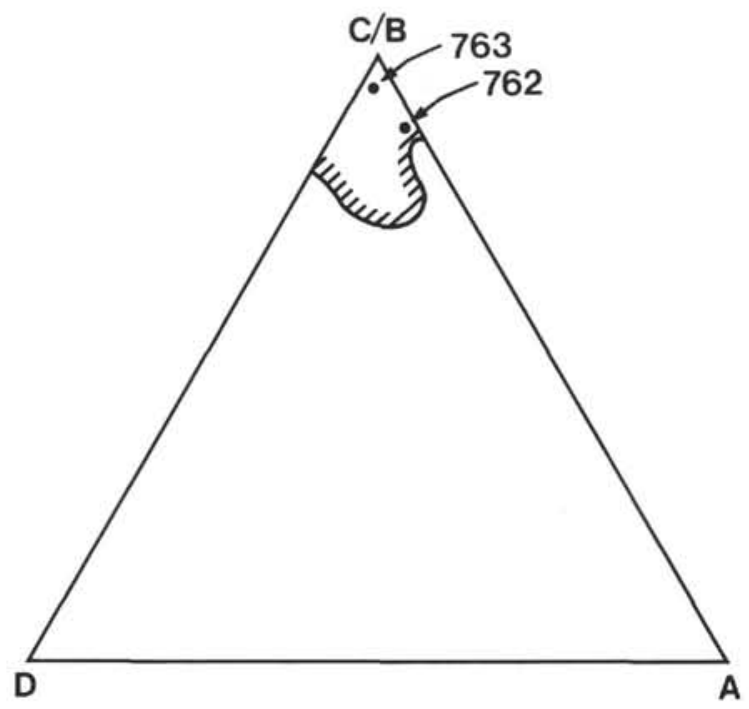

Figure 7. Triangular plot of foraminiferal "morphogroups," Sites 762 and 763. $\mathrm{A}=$ suspension feeders; $\mathrm{C} / \mathrm{B}=$ epifaunal/infaunal detritivores; D = herbivores. Enclosed area is the outer shelf-upper slope field of Jones and Charnock (1985). 

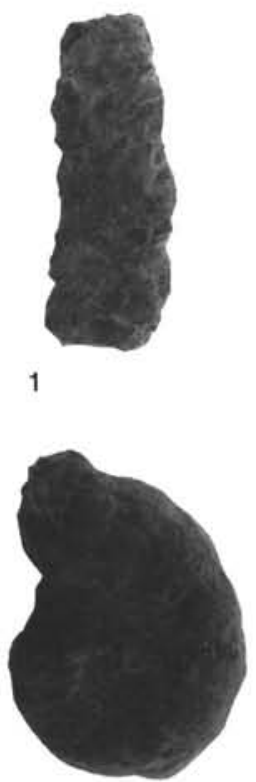

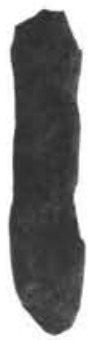

2
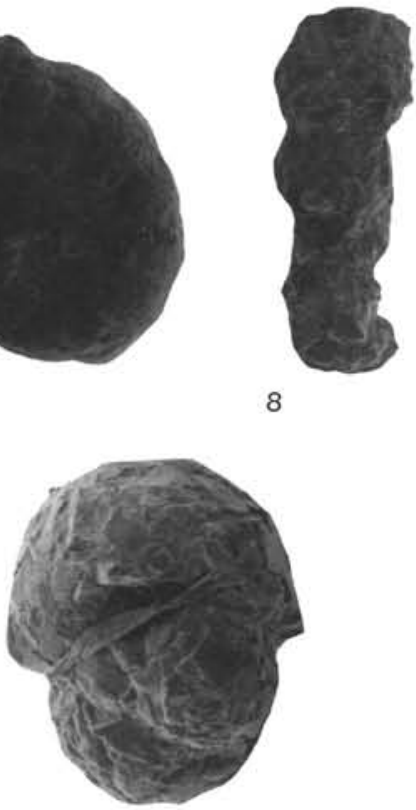

13

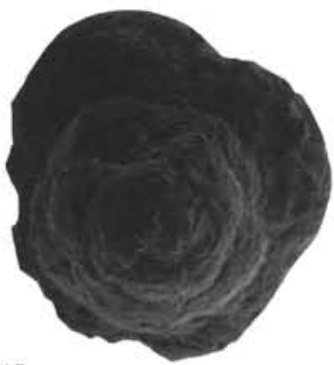

18

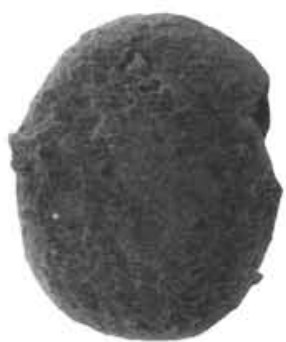

3

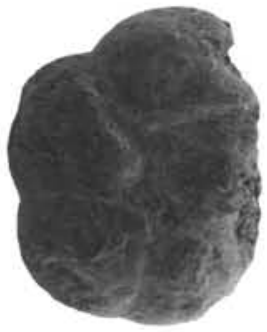

9

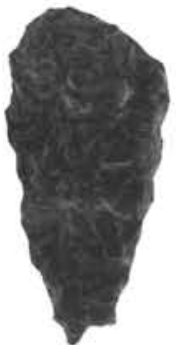

14

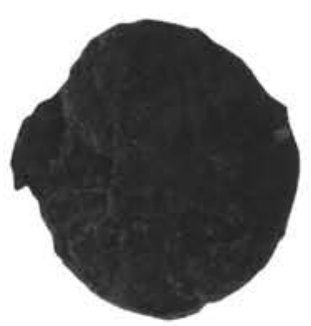

19

4

15
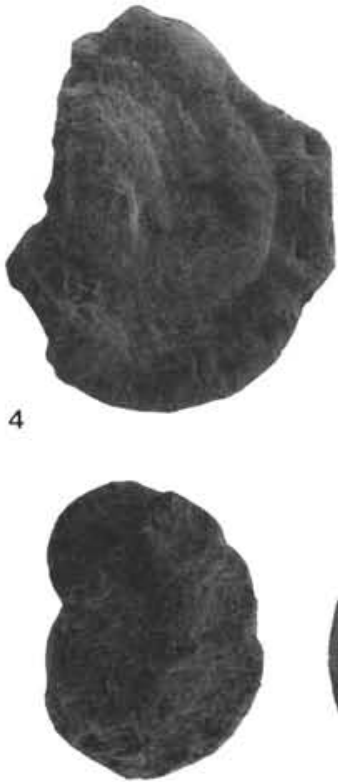

10
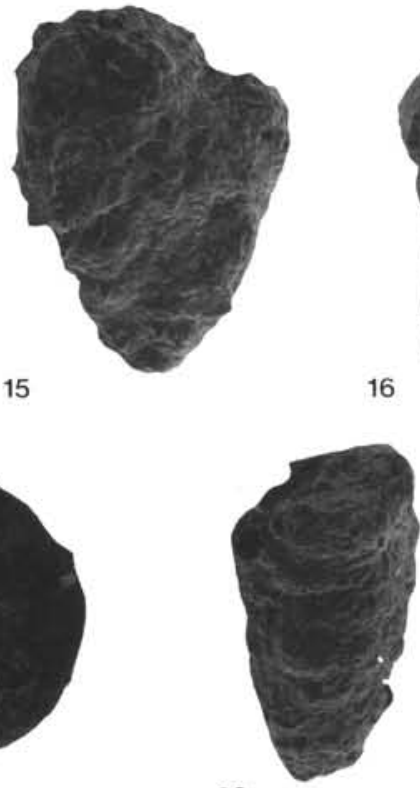

20

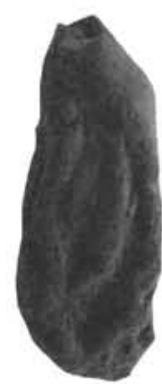

5

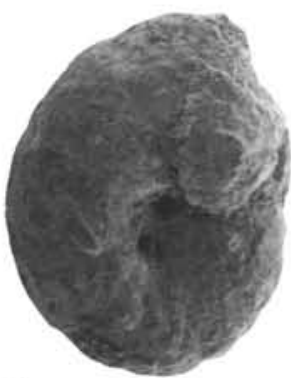

11

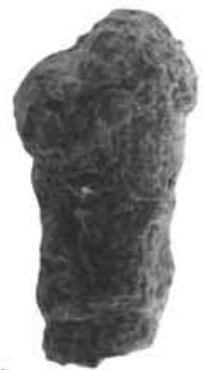

16

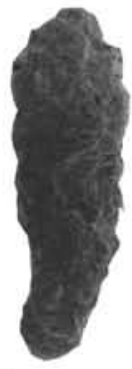

17

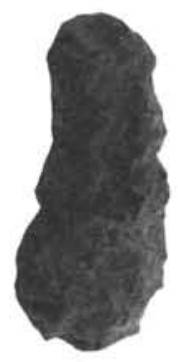

6

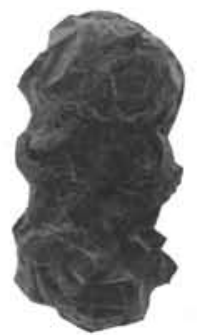

12

Plate 1. Agglutinating foraminifers. 1. Bathysiphon sp., Sample $122-763 \mathrm{C}-31 \mathrm{R}-1,109-111 \mathrm{~cm}, \times 75$. 2. Hyperammina sp., Sample 122-763C37R-2, 109-111 cm, $\times 45$. 3. Ammodiscus sp., Sample 122-763C-25R-2, 109-111 cm, $\times 165$. 4. Glomospira gaultina (Berthelin), Sample 122-763C-21R-2, 109-111 cm, $\times 80.5$. Glomospira sp., Sample 122-763C-21R-2, 109-111 cm, $\times 100.6$. Ammobaculites reophacoides Bartenstein, Sample 122-763C-24R-2, 107-109 cm, $\times 45$. 7. Ammomarginulina $\mathrm{sp}$., Sample $122-763 \mathrm{C}-6 \mathrm{R}-3,28-30 \mathrm{~cm}, \times 37.5 .8$. Haplophragmium inconstans inconstans Bartenstein and Brand, Sample 122-763C-30R-2, 109-111 cm, $\times 40$. 9. Haplophragmoides cushmani Loeblich and Tappan, Sample 122-763C-31R-1, 109-111 cm, $\times 115$. 10. H. cf. infracalloviensis Dain, Sample 122-763C-4R-CC, $\times 100$. 11. H. sp., Sample 122-763C-8R-3, 109-111 cm, $\times 60$. 12. Hormosina sp., Sample 122-763C-34R-2, 109-111 cm, $\times 80$. 13. Praecystammina? sp., Sample 122-763C-24R-2, 107-109 $\mathrm{cm}, \times 90.14$. Textularia bettenstaedti Bartenstein and Oertli, Sample 122-763C-34R-2, 109-111 cm, $\times 110.15 . T$. sp. 1, Sample 122-763C-33R-2, 109-111 cm, $\times 135$. 16. T.? sp., Sample 122-763C-16R-2, 109-111 cm, $\times 125.17$. Spiroplectammina? sp., Sample 122-763C-32R-2, 110-112 cm, $\times 55.18,19$. Trochammina sp., Sample $122-763$ C- $6 \mathrm{R}-3,28-30 \mathrm{~cm}, \times 150.20$. Protomarssonella kummi (Zedler), Sample $122-762 \mathrm{C}-91 \mathrm{X}-1,61-63$ $\mathrm{cm}, \times 125$. 21. Verneuilinoides neocomiensis (Myatliuk) s.l., Sample 122-763C-34R-2, 109-111 cm, $\times 75$. 


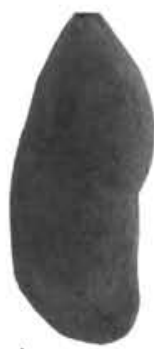

1

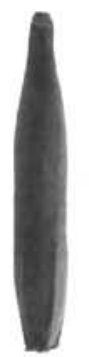

7

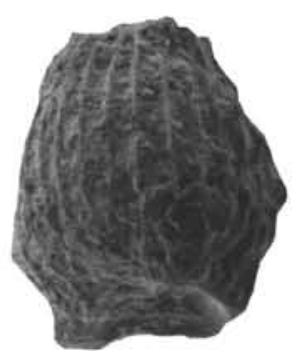

13

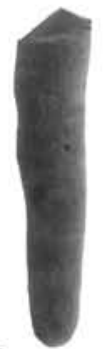

2

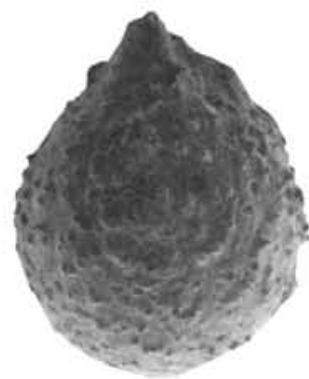

8

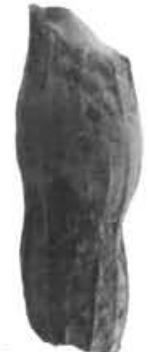

3

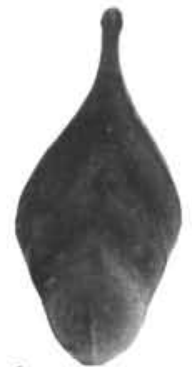

4

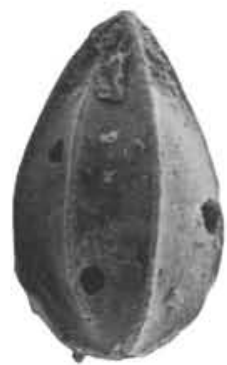

9

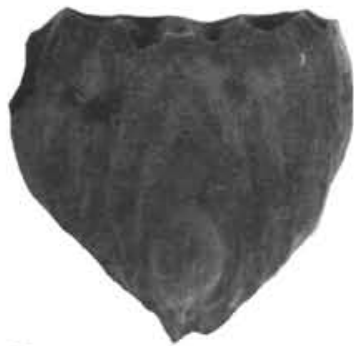

5

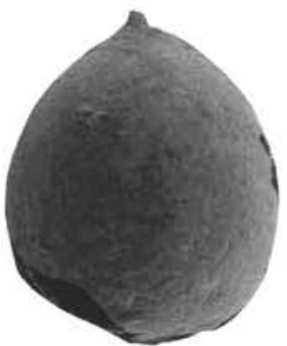

6

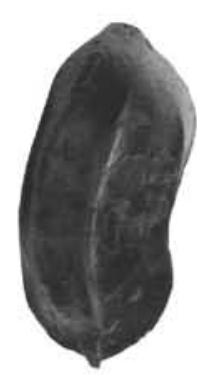

12

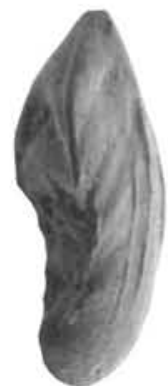

15

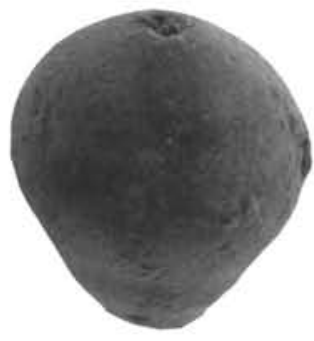

14

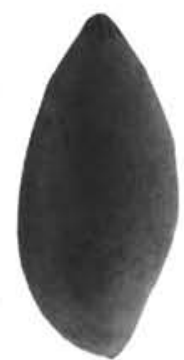

20

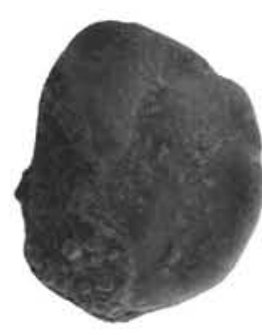

21

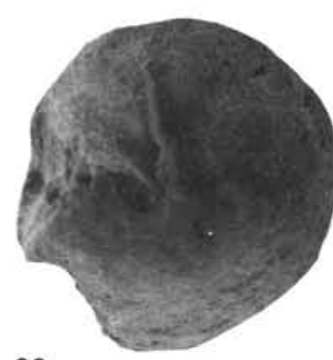

22

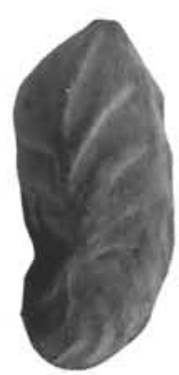

16
10

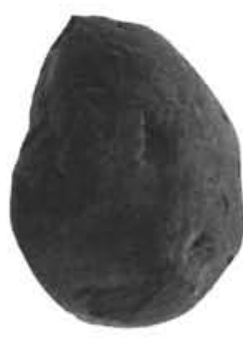

0

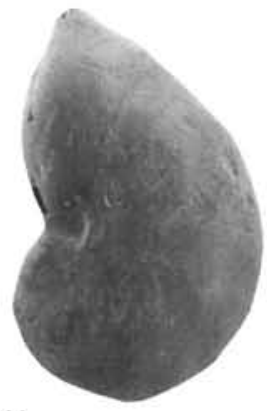

11

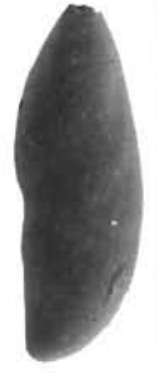

19

Plate 2. Calcareous benthic foraminifers and radiolarians. 1. Astacolus $\mathrm{sp}$., Sample 122-763C-38R-2, 109-111 cm, $\times 75.2$. Dentalina sp. 1, Sample 122-763C-19R-2, 109-111 cm, ×45. 3. D. sp. 2, Sample 122-763C-16R-2, 109-111 cm, ×55. 4. Frondicularia cf. hastata Roemer, Sample 122-763C-21R-2, 109-111 cm, $\times 70$. 5. F. sp., Sample 122-763C-32R-2, 110-112 cm, $\times 60.6$. Lagena neocomiana (Bartenstein and Brand), Sample 122-763C-33R-2, 109-111 cm, ×110. 7. L. sp. 1, Sample 122-763C-21R-2, 109-111 cm, ×65. 8. L. sp. 2, Sample 122-763C-46R-2, 109-111 cm, $\times 110$. 9. $L$. sp. 3, Sample 122-763C-16R-2, 109-111 cm, $\times 150$. 10, 11. Lenticulina ex gr. muensteri (Roemer), Sample $122-763 \mathrm{C}-5 \mathrm{R}-\mathrm{CC}$, $\times 110$ (10); Sample 122-763C-19R-2, 109-111 cm, $\times 100$ (11). 12. Marginulinopsis cf. robusta (Bartenstein and Brand), Sample 122-763C-20R-2, 109-111 $\mathrm{cm}, \times 80$. 13. cf. Nodosaria sceptrum Reuss, Sample $122-763 \mathrm{C}-30 \mathrm{R}-2,109-111 \mathrm{~cm}, \times 125$. 14. Pseudonodosaria cf. humilis (Roemer) Sample 122-763C-8R-3, 109-111 cm, $\times 115.15,16$. Saracenaria valanginiana (Bartenstein and Brand), Sample $122-763 \mathrm{C}-11 \mathrm{R}-1,114-116 \mathrm{~cm}, \times 40$ (15); Sample 122-762C-86X-1, 60-62 cm, $\times 25$ (16). 17. S. sp., Sample 122-763C-16R-2, 109-111 cm, $\times 70$. 18. Vaginulina sp., Sample 122-763C-21R-2, 109-111 cm, $\times 80$. 19. Lingulina sp., Sample 122-763C-31R-1, 109-111 cm, $\times 50$. 20. Polymorphinid indet., Sample 122-763C-7R-2, 109-111 cm, $\times 75$. 21. Conorboides valendisensis Bartenstein and Brand, Sample $122-763 \mathrm{C}-8 \mathrm{R}-3,109-111 \mathrm{~cm}, \times 125.22$. Epistomina caracolla (Roemer), Sample 122-762C-91X-1, 61-63 cm, $\times 135$. 23. Spirillina minima Schacko, Sample 122-763C-38R-2, 109-111 cm, $\times 100.24$. Cenosphaera sp., Sample 122-762C-88X-1, 61-63 cm, ×100. 25. Eucyrtis? sp., Sample 122-763C-5R-CC, $\times 75$. 